\title{
Konjunktiv i fransk og tysk- syntaktisk styret eller semantisk betinget?
}

\author{
Alexandra Holsting \& Jan Lindschouw
}

\begin{abstract}
In this article, we compare the subjunctive in French and German with focus on how this category differs in form and function in the two languages. We investigate how the subjunctive in French displays a restricted inventory of forms compared to German and how syncretism is handled differently in the two languages. We consider these differences a consequence of the functional potential of the subjunctive, which in French is closely connected with specific syntactic structures, whereas the German subjunctive has a more independent meaning potential.
\end{abstract}

Nøgleord: konjunktiv, tysk, fransk, komparativ undersøgelse

\section{Introduktion}

Formålet med denne artikel er at sammenligne konjunktiv i fransk og tysk, både med henblik på form og funktion. Sammenligningen har dermed en verbalbøjningskategori - nemlig modus - som sit tertium comparationis. I både fransk og tysk råder verbet foruden person-, numerus- og tempusbøjning over en modusbøjning med kategorierne indikativ, konjunktiv og imperativ. Vi ser i nærværende artikel bort fra imperativen og koncentrerer os om forskellen på indikativ og konjunktiv, dels hvordan disse er distribueret $\mathrm{i}$ forhold til tempusformerne, dels hvilken betydning de hver især bidrager med enten selvstændigt eller i harmoni med de syntaktiske omgivelser.

Kontrastive undersøgelser af fransk og tysk grammatik er ikke som sådan en ny foreteelse og ses fx i Weber (1954), Zemb (1978), Glinz (1994), Blumental (1987) og Celle (2006), men ingen af disse har et specifikt fokus 
på sammenligningen af konjunktiven og dennes form og funktion i de to sprog. I det omfang denne indgår i fremstillingerne, beskrives den for det enkelte sprog og danner ikke udgangspunkt for en egentlig sammenligning. Eksempelvis er den eneste egentligt sammenlignende kommentar til fænomenet hos Glinz: "Das subjonctif entspricht nur zu einem ganz kleinen Teil dem deutschen Konjunktiv" (1994: 149). Denne diagnose er vi ikke uenige i, for så vidt som konjunktiven dækker forskellige funktionsområder i de to sprog. Formålet i nærværende artikel er imidlertid at pege på hvordan disse forskelle kan klarlægges. ${ }^{1}$

Sammenligningen tager udgangspunkt i en generalisering af den franske konjunktiv som syntaktisk styret og den tyske som semantisk betinget. Med syntaktisk styret menes, at bestemte konstruktioner kræver konjunktiv, som dermed styres af andre grammatiske enheder, mens vi med semantisk betinget mener, at konjunktiv ikke fremkaldes af de syntaktiske omgivelser, men relativt frit kan indsættes i konstruktionen og vil bidrage med en særlig betydning. En beskrivelse af den tyske konjunktiv vil således i høj grad have fokus på betydningen som en selvstændig komponent i modusformen (fx Zifonun et al. 1997), mens beskrivelsen af den franske konjunktiv snarere fokuserer på konjunktivens syntaktiske omgivelser (fx de Boer 1947; Touratier 1996). Dette indebærer dog ikke, at den franske konjunktiv er tømt for betydning, men at denne må fastlægges som en semantisk værdi, der harmonerer med de syntaktiske omgivelser.

Sammenligningen er semasiologisk i sit udgangspunkt - vi går fra form til betydning med det formål at beskrive de måder at udnytte den verbale moduskategori på, som de to sprog udviser. Vi lægger derfor ud med en beskrivelse af forminventaret (afsnit 2), da den formelle organisering efter vores mening i høj grad afspejler det funktionelle potentiale (afsnit 3). Undervejs vil vi sammenligne henholdsvis forminventar og funktionelt potentiale.

\section{Forminventar}

Verbernes bøjningsparadigmer er organiseret forskelligt på de to sprog. Fransk opererer i lighed med andre romanske sprog med tre hovedbøjningsformer: 1. bøjning (verber der i infinitiv ender på -er, fx parler 'at tale'), 2.

1. En bredere sammenligning af modus med udgangspunkt i alle europæiske sprog findes i Thieroff (2010). Her er der dog tale om flere sprog og mere overordnede typologiske sammenligninger end tilfældet er her, hvor fokus er specifikt på den systematiske fremstilling af konjunktivens form- og funktionsområder i tysk og fransk. 
bøjning (verber med infinitiv på -ir, fx finir 'at slutte') og 3. bøjning (verber med infinitiv på -re, fx vendre 'at sælge'). Hertil kommer en række uregelmæssige verber. Tysk skelner i lighed med andre germanske sprog mellem stærke verber, der danner præteritum vha. vokalveksel (sterben (inf) 'at dø' $\rightarrow$ er starb (præt)), og svage verber, der danner præteritum vha. suffikset -te (leben (inf) 'at leve' $\rightarrow$ er lebte (præt)). Dette har konsekvenser for modusbøjningen og graden af synkretisme mellem indikativ og konjunktiv på begge sprog.

\subsection{Forminventar på fransk}

Det franske indikativparadigme er morfologisk langt mere righoldigt end konjunktivparadigmet. I indikativ findes der fire overordnede tempora, der kan opdeles i en usammensat og en sammensat variant, forankret ud fra nutids-, fortids-, fremtids- og fortidsfremtidsplanet. På fortidsplanet er der to usammensatte og to sammensatte verbalformer, hvilket hænger sammen med datidsplanets opdeling i to aspektplaner (perfektiv og imperfektiv).

På konjunktivsiden er forminventaret langt mere begrænset. Her findes kun fire former: to, der er forankret i nutidsplanet (præsens og perfektum), og to, der er forankret i fortidsplanet (imperfektum og pluskvamperfektum).

\begin{tabular}{|l|l|l|}
\hline & Indikativ & Konjunktiv \\
\hline Præsens & il sent & il sente \\
\hline Perfektum & il a senti & il ait senti \\
\hline Imperfektum & il sentait & il sentit \\
\hline Pluskvamperfektum & il avait senti & il eût senti \\
\hline $\begin{array}{l}\text { Præteritum } \\
\text { (usammensat) }\end{array}$ & il sentit & \\
\hline $\begin{array}{l}\text { Præteritum } \\
\text { (sammensat) }\end{array}$ & il eut senti & \\
\hline Futurum (usammensat) & il sentira & \\
\hline Futurum (sammensat) & il aura senti & \\
\hline $\begin{array}{l}\text { Konditionalis } \\
\text { (usammensat) }\end{array}$ & il sentirait & \\
\hline $\begin{array}{l}\text { Konditionalis } \\
\text { (sammensat) }\end{array}$ & il aurait senti & \\
\hline
\end{tabular}

Tabel 1. Forminventar (indikativ, konjunktiv) på fransk illustreret vha. verbet sentir 'at fole' $i$ 3. person singularis

Det betyder, at hvis man fx vil udtrykke noget om fremtiden, må man bruge en almindelig præsens konjunktiv i en afhængig sætning som i (1):

(1) Pierre est content que Marie vienne (PRÆS KONJ) demain. 'Pierre er glad for, at Marie kommer i morgen.' 
Det skal samtidigt bemærkes, at konjunktivparadigmet i den konkrete sprogbrug er endnu mere reduceret, end skemaet giver udtryk for (se $\mathrm{fx}$ Kragh 2010). I praksis er imperfektum og pluskvamperfektum så godt som ikke-eksisterende og findes kun i formelle tekstgenrer (taler, højstemt prosa, poesi o.l.) (2), hvor de optræder som et udtryk for consecutio temporum:

$$
\begin{aligned}
& \text { Pierre était content que Marie vînt (IMP KONJ) le lendemain. } \\
& \text { 'Pierre var glad for, at Marie kom den følgende dag.' }
\end{aligned}
$$

Typisk undgår man de lange fortidsformer i imperfektum konjunktiv, ${ }^{2}$ så derfor vil man i dagligdags sprogbrug i stedet bruge en almindelig præsens konjunktiv, selvom matrixverbet står i en fortidsform (3). Det betyder, at der ikke længere er en temporal distinktion (nutid-fortid) i konjunktivparadigmet, men snarere en aspektuel forskel (perfektiv-imperfektiv):

Pierre était content que Marie vienne (PRÆS KONJ) le lendemain.

'Pierre var glad for, at Marie kom den følgende dag.'

Det diskuteres inden for fransk lingvistik, om konditionalisformerne skal opfattes som en del af indikativparadigmet, eller om de udgør en selvstændig modus (Lindschouw 2017). I den nordiske tradition opfattes konditionalis som en del af indikativparadigmet (Pedersen et al. 1994: 336f; Togeby 1982: 50). Argumentet herfor er bl.a., at den kan angive fortidens fremtid, dvs. fungere som en variant for tempusformen futurum efter et overordnet verbal i fortid (jf. (4) og (5)). Argumentet for at kategorisere den som en modus er, at den kan angive forskellige modale indhold, når den bruges i hovedsætninger, fx hypotese (6) eller rygte/forlydende (7):

(4) Pierre viendra (FUT IND) demain.

'Pierre vil komme i morgen.'

$$
\begin{aligned}
& \text { Marie a dit que Pierre viendrait (KOND IND) le lendemain. } \\
& \text { 'Marie sagde, at Pierre ville komme den efterfølgende dag.' }
\end{aligned}
$$

2. I eksempel (2) er imperfektum konjunktiv imidlertid ikke lang, men det ville den være i 1. og 2. person singularis og pluralis (je vinsse, tu vinsses, nous vinssions, vous vinssiez ('jeg/du/vi/I kom')). Derfor findes imperfektum konjunktiv praktisk taget kun i 3. person (singularis) som i eksemplet ovenfor. 
(6) Si tu venais demain, je serais (KOND IND) content.

'Hvis du kom i morgen, ville jeg blive glad.'

(7) Le président serait (KOND IND) souffrant.

'Præsidenten skal være syg.'

Tabel 1 angiver et verbum, hvor indikativ og konjunktiv er tydeligt forskellige fra hinanden. Det skal dog bemærkes, at ved den højfrekvente og produktive verbalgruppe 1 (verber på -er) er der en høj grad af synkretisme mellem præsens indikativ og præsens konjunktiv (1./2./3.sg samt 3.pl).

\subsection{Forminventar på tysk}

Beskrivelsen af forminventaret på tysk kan se ud på forskellige måder (fx Jørgensen 1995; Zifonun et al. 1997; Fabricius-Hansen 2009), hvilket i nogen grad afspejler, at denne beskrivelse afhænger af, hvordan funktionspotentialet anskues. Alene betragtet ud fra morfologisk gestaltning kan følgende oversigt over tempusformerne i hhv. indikativ og konjunktiv opstilles:

\begin{tabular}{|l|l|l|}
\hline & Indikativ & Konjunktiv \\
\hline Præsens & er lebt / stirbt & er lebe / sterbe \\
\hline Perfektum & er hat gelebt / ist gestorben & er habe gelebt / sei gestorben \\
\hline Futurum & er wird leben /sterben & er werde leben / sterben \\
\hline Præteritum & er lebte /starb & er lebte / stürbe \\
\hline Pluskvamperfektum & er hatte gelebt /war gestorben & $\begin{array}{l}\text { er hätte gelebt / wäre } \\
\text { gestorben }\end{array}$ \\
\hline Würde & & er würde leben / sterben \\
\hline
\end{tabular}

Tabel 2. Forminventar (indikativ, konjunktiv) på tysk illustreret vha. verberne leben og sterben $i$ 3.sg.

Verberne leben og sterben repræsenterer hhv. svage og stærke verber. Som oversigten illustrerer, er der tale om distinkte former i alle tempora - eneste undtagelse er det svage verbum i præteritum (lebte). Dog udviser det samlede system en høj grad af synkretisme; både svage og stærke verber har sammenfald i præsens, perfektum og futurum i 1.sg, 1.pl og 3.pl. og i futurum i 2.pl. Kun verbet sein har distinkte former i alle person-numeruskonstellationer og alle tempora.

Tabel 2 angiver en tom plads i indikativparadigmet, idet systemet ikke råder over en indikativisk parallelform til würde + Ø-infinitiv (*wurde leben). Ud fra en streng morfologisk vinkel er würde præteritum konjunktiv af werden; brugen af formen i indikativisk kontekst til angivelse af fortids fremtid medfører dog, at nogle anser den for både indikativisk og konjunktivisk ( $\mathrm{x}$ Jørgensen 1995: 38). 
Tempusbetegnelserne i tabellen fungerer alene som angivelser af den formelle parallelitet mellem modussystemerne og tager ikke højde for de temporale forskelle mellem indikativ og konjunktiv. Hvor tempusformerne $\mathrm{i}$ indikativ angiver absolut tid (præsens kan bruges om nutid, præteritum om fortid etc.), fordeler konjunktivformerne sig over forskellige funktionsområder. De tre overordnede modale områder opfordring, irrealitet og referat (se afsnit 3) dækkes af hhv. de præsensbaserede former (konjunktiv I), de præteritumsbaserede former (konjunktiv II) eller alle former: ${ }^{3}$

\begin{tabular}{|l|l|c|}
\hline \multicolumn{2}{|l|}{ Konjunktiv I (præs, perf, fut) } & \multicolumn{2}{c|}{ Konjunktiv II (præt, plusk, würde) } \\
\hline Opfordring $^{4}$ & Referat & Irrealitet \\
\hline
\end{tabular}

Inden for disse områder realiserer formerne forskellige relative tidsbetydninger (samtid, førtid, eftertid). Nedenfor er dette illustreret med eksempler på referat, hvor begge systemer anvendes:

(8) Er sagt/sagte, seine Schwester habe (PReS KONJ) keine Zeit.

(9) Er sagt/sagte, seine Eltern hätten (PRÆT KONJ) keine Zeit.

'Han siger/sagde, at hans søster/hans forældre ikke har tid.'

Både præsens og præteritum anvendes således til at udtrykke samtidighed. Helt overordnet er tendensen, at konjunktiv I anvendes, hvis den er tydelig (8); alternativt anvendes konjunktiv II (9). Som udtryk for førtidighed anvendes perfektum (10) eller pluskvamperfektum (11):

(10) Er sagt/sagte, seine Schwester habe keine Zeit gehabt (PERF KONJ).

(11) Er sagt/sagte, seine Eltern hätten keine Zeit gehabt (PLUSK KONJ). 'Han siger/sagde, at hans søster/hans forældre ikke har haft tid.'

3. Betegnelserne 'konjunktiv I' og 'konjunktiv II' antager en blandet status mellem form og funktion, som bl.a. udfordres i Jakobsen \& Heltoft (2012) og Jakobsen (2013), hvor det foreslås at operere med et tredje system, 'konjunktiv III', der omfatter alle konjunktivformer og funktionelt dækker referatet.

4 Der skal ikke her antages et 1:1-forhold mellem betydningskategorierne og formkategorierne; de pågældende betydningskategorier kan realiseres gennem andre sproglige former end de her angivne; formålet med skemaet er alene at angive funktionsområderne for de to konjunktivsystemer. 
Endelig bruges futurum (12) eller wïrde-formen (13) for eftertidighed: ${ }^{5}$

(12) Er sagt/sagte, seine Schwester werde keine Zeit haben (FUT KONJ).

(13) Er sagt/sagte, seine Eltern wü̈rden keine Zeit haben (WÜRDE-FORM).

Her spiller det dog en rolle, at wïrde-formen har en (anden) central funktion, idet den optræder som analytisk parallelform til præteritum (Zifonun et al. 1997: 1736). Den analytiske würde-form anvendes hyppigt, når den syntetiske præteritum konjunktiv har formsammenfald med indikativ. Det gælder som nævnt for de svage verber jf. (14):

(14) Wenn ich [im Nahen Osten] leben würde (WÜRDE-FORM) und eine Familie hätte (PRÆT KONJ), wïrde ich auch fliehen wollen. (www.radio.cz) 'Hvis jeg boede i Mellemøsten og havde en familie, ville jeg også flygte.'

Fremfor tvetydig syntetisk præteritum lebte bruges her analytisk würde leben. Den temporale parallelitet understreges af den parataktiske konstruktion med syntetisk præteritum hätte.

Denne brug af würde-formen synes motiveret af behovet for en tydelig konjunktiv. Den forekommer dog også ved stærke verber, hvor præteritum konjunktiv godt nok er distinkt, men forekommer usædvanlig eller vanskelig (jf fx Fabricius-Hansen 2009: 530); i (15) gælder dette übertragen (synt. præt.: übertrüge):
[Die Wellenlängen] sind so enorm, dass man sie an den einzelnen Teleskop- standorten aufzeichnen und die Festplatten dann per Flugzeug zu den Rechen- zentren transportieren muss, wo sie korreliert werden. Würde man die Daten per Internet übertragen, würde das fahre dauern. (www.faz.de) 'Bølgelængderne er så enorme, at man må optegne dem på det enkelte teleskopsted og derpå transportere harddiskene med fly til datacentralerne, hvor de bliver samkørt. Overførte man dataene per internet, ville det tage år.'

5. Parallelt med forholdene i indikativ, hvor fremtid kan udtrykkes ved hjælp af futurum eller præsens (er wird morgen keine Zeit haben 'han vil ikke have tid i morgen'/ er hat morgen keine Zeit 'han har ikke tid i morgen'), kan også præsens og præteritum konjunktiv anvendes ved eftertidighed (jf. Zifonun et al. 1997: 1737). 
Bemærk, at der i (15) også anvendes würde-form af det svage verbum dauern (synt. præt.: dauerte). Generelt antages anvendelsen af de to former at være registerspecifik, således at der ses relativt flere analytiske former i uformelle registre end i formelle (jf. fx Bausch 1979).

Würde-formens status som analytisk præteritum konjunktivform er interessant for så vidt som den vidner om, at det i tysk er centralt at anvende en tydelig konjunktivform.

\subsection{Sammenligning}

Som det forudgående har vist, adskiller de to sprog sig ved, at fransk har et reduceret konjunktivparadigme med væsentlig færre former end i indikativparadigmet. Tysk har derimod et fuldt udbygget konjunktivsystem; hver indikativisk tempusform har en morfologisk set tilsvarende konjunktivform.

I begge sprog ses en del synkretisme mellem indikativ- og konjunktivformerne, men sprogene forholder sig til dette på forskellig vis. Fransk bruger formerne, uanset om der er sammenfald eller ej, og udviser endvidere tendens til at erstatte tydelig imperfektum konjunktiv med en utydelig præsens konjunktiv, bl.a. i de tilfælde, hvor imperfektum konjunktiv resulterer i lange former og komplicerede bøjningsendelser (især i 1./2.sg og pl). I tysk ses det derimod ofte, at utydelige konjunktivformer erstattes med tydelige. Det ses fx i sammenhænge, hvor både konjunktiv I og II kan anvendes, og hvor konjunktiv II typisk bruges for at sikre en tydelig konjunktivform.

En yderligere forskel på de to formsystemer vedrører konditionalis. På fransk ses konditionalis typisk som en del af indikativsystemet men med sit eget funktionsområde. På tysk kan der ikke som på fransk identificeres en særskilt konditionalisform, idet kandidaten til denne form, würde-formen, deler funktionsområde med præteritum konjunktiv i uformelt register. Konditionalis på fransk dækker i et vist omfang noget af konjunktivs anvendelsesområde på tysk.

Vores formanalyse viser desuden, at der principielt er consecutio temporum i fransk, som dog er ophævet i praksis pga. bortfald af imperfektum og pluskvamperfektum konjunktiv i uformelt register. Derimod er der ingen consecutio temporum i tysk, fordi konjunktiv I og II er temporalt sammenfaldende, og der således kan være fri udskiftning mellem fx præsens konjunktiv og præteritum konjunktiv. ${ }^{6}$

Som konsekvens heraf kan man sige, at der er en aspektuel opposition

6. Ifølge Bravo (1980) udviste tysk på tidligere sprogtrin consecutio temporum, således at referatkonjunktivens tempusform harmonerede med inquitverbets. 
mellem præsens og perfektum konjunktiv på fransk (perfektiv - imperfektiv), som til en vis grad svarer til skellet mellem samtidighed og førtidighed på tysk.

\section{Funktionsbeskrivelse}

\subsection{Fransk}

Der hersker ikke nogen tvivl om, at den franske konjunktiv i vid udstrækning er styret af de syntaktiske omgivelser og således kan opfattes som et ledsætningsfænomen (de Boer 1947; Harris 1974; Touratier 1996). Dette hænger i høj grad sammen med den sproglige udvikling, idet konjunktiv på ældre sprogtrin, fx old- og middelfransk, var langt mere udbredt i hovedsætninger, end tilfældet er i dag, hvor konjunktiv kun optræder i faste udtryk med optativisk funktion (16) eller som variant for imperativ i 3. person (17):

(16) Vive (KONJ) le président, vive (KONJ) la république.

'Længe leve præsidenten, længe leve republikken.'

(17) Qu'il soit $(\mathrm{KONJ})$ de retour à 8 heures.

'Han skal være hjemme klokken 8.'

På grund af konjunktivens status som ledsætningsænomen har nogle forskere hævdet at den skal ses som betydningstom (Foulet 1968; Harris 1974; Prebensen 2002). Mod dette skal dog indvendes, at konjunktiven ikke optræder i alle ledsætninger, men anvendes i harmoni med bestemte matrixprædikater og subjunktioner. Udelades konjunktiven her, opfattes det som, om ikke ugrammatisk, så stigmatiserende, i hvert fald i en skolefaglig kontekst, og af den veluddannede franske middel- og overklasse.

Imidlertid hersker der ikke fuldstændig enighed om, hvilken værdi konjunktiv skal tilskrives, og i løbet af det tyvende århundrede har der været fremsat mange forskellige bud på dette, nogle mere overbevisende end andre (se Lindschouw (2011: 25-65) for en udførlig gennemgang). Således hævder nogle forskere, at konjunktiv udtrykker subjektivitet, mens indikativ udtrykker objektivitet (van der Molen 1923; Le Bidois \& Le Bidois 1935), hvorimod andre ser konjunktiv som udtryk for tvivl og irrealis, mens indikativ udtrykker sikkerhed og realis (Brunot 1922; Martin 1992). Problemet med disse binære definitioner er, at de forsøger at reducere konjunktivs og indikativs betydning til én snæver grundbetydning, der skal kunne forklare samtlige forekomster. Imidlertid er det nemt at finde modeksempler til disse værdier. Man kan fx med rette spørge, hvori konjunktivs irreale betydning ligger i (18), og hvori indikativs påståede reale betydning ligger i (19): 
(18) Bien qu'il pleuve (KONJ), Pierre se promène dans le jardin. 'Selvom det regner, går Pierre en tur i haven.'

(19) Il se figure qu'il est (IND) capable de courir cinq kilomètres en dix minutes. 'Han bilder sig ind, at han er i stand til at løbe fem kilometer på ti minutter.'

En indkredsning af indikativs og især konjunktivs forskelligartede og til dels modstridende betydninger på fransk kræver derfor, at man opererer med nogle bredere semantiske kategorier. Et bud på dette er assertionsteorien, der hævder, at indikativ som modus er asserterende, mens konjunktiv er ikke-asserterende (Hooper 1975; Korzen 1999). Med termen 'assertion' skal forstås ny information, som afsender selv kan stå inde for sandhedsværdien af (20), mens ikke-assertion enten skal forstås som noget non-reelt, dvs. et sagsforhold, der endnu ikke er realiseret på taletidspunktet (21), eller som det helt modsatte, dvs. kendt, faktuel eller præsupponeret information (18):

(20) Il a raconté que la France avait (IND) gagné 3 à 0 contre le Danemark. 'Han fortalte, at Frankrig havde slået Danmark 3-0.'

(21) Je veux que tu ne fasses (KONJ) plus de bêtises.

'Jeg vil have, at du ikke begår flere dumheder.'

Dette begrebspar synes at kunne forklare hovedparten af modusformernes anvendelse på moderne fransk i de tre overordnede sætningstyper, hvor indikativ og konjunktiv kan forekomme, både i kontekster, hvor kun én modus er mulig, og i de kontekster, hvor indikativ og konjunktiv varierer med hinanden.

Det gælder således i kompletivsætninger, hvor konjunktiv udtrykker noget ikke-asserteret både efter udtryk for vilje og ønske (22) og benægtede udtryk for mening og ytring (23). I begge disse tilfælde angiver konjunktiv nærmere bestemt noget non-reelt:

(22) "Il faut que tu sois (KONJ) de retour à o heures"

'Det er nødvendigt, at du er hjemme kl. 8.'

(23) Je ne crois pas que Pierre le fasse (KONJ).

'Jeg tror ikke, at Pierre vil gøre det.' 
Men det gælder også kompletivsætninger efter udtryk for subjektiv vurdering (24) og kompletivsætninger, der er foranstillet matrixprædikatet (25). I begge disse tilfælde kan konjunktiven siges at angive kendt/præsupponeret information:

(24) Je suis content que tu ailles (KONJ) mieux.

'Jeg er glad for, at du har det bedre.'

(25) Que Pierre ne vienne (KONJ) pas à la réunion est certain.

'At Pierre ikke kommer til mødet er sikkert.'

Dog findes der også eksempler i kompletivsætninger, hvor konjunktiv og indikativ tilfører matrixprædikatet to forskellige læsninger, hvorved ledsætningsindholdet bliver hhv. asserteret (26) og ikke-asserteret (27). Dette er en indikation af, at konjunktiv i disse kontekster er semantisk motiveret:

(26) Je comprends que Pierre ne vient (IND) pas à la réunion.

'Jeg forstår/hører, at Pierre ikke kommer til mødet.'

(27) Je comprends que Pierre ne vienne (KONJ) pas à la réunion. 'Jeg kan godt forstå, at Pierre ikke kommer til mødet.'

I relativsætninger forefindes begge modi på fransk, og også her må konjunktiv siges at være semantisk bærende, da indikativ og konjunktiv varierer med hinanden med en tydelig betydningsforskel til følge. Det gælder især efter non-referentielt korrelat efter udtryk for vilje, ønske eller søgen. I (28) asserterer indikativ i relativsætningen, at det pågældende hus findes, mens afsender med brugen af konjunktiv ikke tager stilling til, om et sådant hus findes eller ej.

(28) Je cherche une maison qui a (IND) / ait (KONJ) une vue splendide sur la mer. 'Jeg leder efter et hus, der har en smuk udsigt til havet.'

I nogle typer af relativsætninger er konjunktiv dog obligatorisk på fransk. Det gælder efter superlativ og superlativiske udtryk, hvor konjunktiv præsupponerer ledsætningsindholdet:

(29) Tu es la femme la plus intelligente que je connaisse (konj).

'Du er den mest intelligente kvinde, jeg kender.' 
I adverbielle ledsætninger er modusformerne med visse undtagelser ${ }^{7}$ begrænset til forskellige styrere. Konjunktiv optræder som obligatorisk modus med en ikke-assertiv tolkning efter tidssubjunktionerne avant que ('inden') og jusqu'à ce que ('indtil') (30), hensigtssubjunktionerne pour que, afin que, de façon/manière à ce que ('for at') (31), de faktuelle indrømmelsessubjunktioner bien que, quoique og encore que ('skønt') (32) samt efter mådessubjunktionen sans que ('uden at') (33):

(30) Rentre avant qu'il ne fasse (KONJ) nuit.

'Kom hjem inden det bliver mørkt.'

(31) On a accroché la pendule au-dessus de la porte pour que tout le monde puisse (KONJ) la voir.

'Uret er blevet anbragt oven over døren, for at alle skal kunne se det.'

(32) Bien qu'il pleuve (KONJ), Pierre se promène dans le jardin.

'Selvom det regner, går Pierre en tur i haven.'

(33) Il est parti sans que sa mère s'en soit (KONJ) rendu compte.

'Han tog af sted, uden af hans mor lagde mærke til det.'

Disse eksempler vidner om, at konjunktiv på moderne fransk i vid udstrækning er bundet til den syntaktiske kontekst, men at den inden for disse rammer udtrykker en bestemt semantisk værdi (ikke-assertion) og således ikke bare er et historisk levn, der bruges mere eller mindre tilfældigt i en række forskellige kontekster.

\subsection{Tysk}

Den tyske konjunktiv er ikke som den franske knyttet til ledsætningen og dermed heller ikke til bestemte matrixprædikater eller subjunktioner. Snarere er der tale om en selvstændig grammatisk ressource, der kan bidrage med sin betydning i både hovedsætning, hvor den alene udtrykker den pågældende betydning, og ledsætning, hvor betydningen etableres gennem matrixprædikat eller subjunktion og understøttes af konjunktiven.

7. Det gælder især inden for subjunktioner, der både kan udtrykke følge og hensigt (de sorte/manière/ façon que), hvor indikativ angiver følge ('således at') og konjunktiv hensigt ('for at'). 
Overordnet kan konjunktiven tilskrives tre hovedfunktioner, der er knyttet til hvert sit forminventar. Konjunktiv I kan forekomme med opfordrende betydning, konjunktiv II med irrealis / potentialis-betydning, og begge systemers former kan forekomme med referatbetydning. Da den førstnævinte funktion er begrænset, vil vi i det følgende fokusere på de to sidstnævnte.

\subsubsection{Irrealis / potentialis}

Konjunktiv II-formerne varetager det felt, der betegnes 'irrealis', 'potentialis' eller i nogle sammenhænge 'eventualis'. Med konjunktiv fremstilles det beskrevne forhold som stående i opposition til reelle forhold. Den videre inddeling kan så beskrive om, der er tale om noget egentligt kontrafaktisk eller et forhold, der ikke er gældende, men stadig lader sig realisere (her spiller pragmatiske faktorer en større rolle end de grammatiske).

Med denne funktion kan konjunktiven optræde selvstændigt (som eneste irrealismarkør) (34) eller i forbindelse med en subjunktion, der i sig selv angiver forholdet som irreelt (35):

Das wäre (KONJ) eine Katastrophe.

'Det ville være en katastrofe.'

Er ging weg, ohne dass wir es gemerkt hätten (KONJ).

'Han gik væk, uden at vi bemærkede det.'

Mens en udskiftning af konjunktiven wäre med indikativ ist $\mathrm{i}(34)$ vil føre til en realisforankring af udsagnet (das ist eine Katastrophe), vil en indikativ i (35) (merkten) ikke medføre en ændring af forankringen, der etableres af ohne dass. Brugen af konjunktiv i sådanne konstruktioner opfattes således ikke som obligatorisk. ${ }^{8}$

\subsubsection{Referat}

Konjunktiv I og II kan tjene til angivelse af referat. Herunder forstås både den syntaktisk underordnede indirekte tale som kompletivsætning og den syntaktisk selvstændige refererende sætning:

8. En særlig type udgør irreale sammenligningssætninger indledt af als ob ('som om') og lignende subjunktioner. Modsat øvrige irreale sætninger kan de indeholde konjunktivformer fra begge systemer; herudover er også indikativ mulig, da det irreale indhold angives af subjunktionen:

(a) Er sah aus, als ob er tief schlafe (PRÆS KONJ)/schliefe (PRÆT KONJ)/schlief (PR ET INDIK).

'Han så ud, som om han sov dybt.' 
(36) Theresa May hat wiederholt klargemacht, dass ihr Land nicht nur die EU, sondern auch deren Binnenmarkt und die Zollunion verlassen werde (KONJ). Denn nur wenn man sich den Regeln der EU nicht unterwerfe (KONJ), könne (KONJ) man die Zuwanderung aus der EU begrenzen. (www.spiegel.de)

'Theresa May har gentagne gange gjort klart, at hendes land ikke kun vil forlade EU, men også det indre marked og toldunionen. For kun hvis man ikke underkaster sig EU's regler, kan man begrænse indvandringen fra EU.'

Hvor dass-sætningen er underordnet inquitverbet klarmachen og referatbetydningen underbygges af verlassen werde (fut konj), står denn-sætningen som en fri hovedsætning; her udtrykkes referatbetydningen alene gennem verballeddets konjunktivform könne (samt verballeddet i adverbialsætningen unterwerfe) (begge præs konj).

I (36) anvendes konjunktiv i kompletivsætning, således at referatbetydningen etableres af inquitverbum og konjunktiv. Ligesom det er tilfældet for irrealis, er referatkonjunktiven i mindre grad nødvendig, når referatbetydningen etableres et andet sted i sætningen. I den referende kompletivsætning ses der derfor også indikativ som i (37):

(Rupert Sheldrake glaubt, dass Menschen und Tiere übersinnliche Fähigkeiten besitzen. [...]) Er behauptet, dass er dies wissenschaftlich bezeisen kann (IND). (www.zeit.de)

'Rupert Sheldrake tror, at mennesker og dyr besidder oversanselige egenskaber. Han hævder, at han kan bevise dette videnskabeligt.'

Her etableres referatbetydningen af det overordnede inquitverbum (behauptet), og der kunne uden problemer have været anvendt konjunktiv i kompletivsætningen (beweisen könne). Muligheden for indikativ fremmes af, at der tydeligt er tale om en kompletivsætning (i form af bisætningsstrukturen og subjunktionen dass). Referatkompletivsætninger med hovedsætningsstruktur ses i mindre grad med indikativ (er behauptet, er kann dies beweisen), hvilket kan have at gøre med risikoen for, at den indirekte tale forveksles med direkte tale.

Selvom tendensen til indikativ i referatkompletivsætningen ikke er så stærk som den tidligere nævnte tendens i irreale ledsætninger, er der dog også her tale om, at konjunktiven ikke alene etablerer den givne betydning, og at den derfor principielt kan udelades. 
En række fremstillinger (fx Fabricius-Hansen 2009; Eisenberg 2006; Kaufmann 1976) identificerer et særligt tilfælde, hvor modusvalget er betydningsbærende på en måde der er delvist sammenlignelig med det franske i (26) og (27). Det gælder konstruktioner, hvor referatkonjunktiven optræder i kompletivsætningen for et matrixprædikat, der tillader både en faktiv læsning og en inquitlæsning, fx kritisieren (jf. Fabricius-Hansen 2009: 533), der kan angive, at agenten kritiserer et faktisk forhold udtrykt af kompletivsætningen, der dermed optræder med præsupponeret status, eller at agenten ytrer sig på kritiserende vis, hvorved kompletivsætningen gengiver indholdet af ytringen:

\section{Söder kritisierte, dass Merkel erneut ihren Satz "Wir schaffen das" wieder-}

holt hat (IND). (www.zeit.de)

'Söder kritiserede, at Merkel på ny har gentaget sætningen "Vi klarer det."

Erdoğan kritisierte, dass sein Land so häufig Thema in Deutschland sei (KONJ). (www.zeit.de)

'Erdoğan kritiserede, at hans land så hyppigt er et tema i Tyskland.'

Antagelsen i førnævnte fremstillinger er, at modusvalget styrer læsningen af matrixprædikatet, således at indikativ tillader både en inquitlæsning og en faktiv læsning (38), mens konjunktiv fastlægger det som inquit ('sige kritiserende') (39).

\subsection{Sammenligning}

Analysen af funktionsområder viser, at konjunktiv overvejende er syntaktisk motiveret på fransk, idet konjunktiv primært optræder i ledsætninger, hvor den styres af matrixprædikatet eller subjunktionen. Den er dog ikke uden semantisk indhold, idet de styrende elementer harmonerer med konjunktivens ikke-asserterende betydning. Konjunktiv er derfor som udgangspunkt ikke selvstændig bærer af semantisk indhold, om end vi har set eksempler på dette, se (26)-(28).

På tysk er konjunktiv overvejende semantisk motiveret og findes både i hoved- og ledsætninger. I nogle sammenhænge er der tale om en relation som i fransk, hvor konjunktiv harmonerer med de syntaktiske omgivelser, men her er konjunktiv ikke obligatorisk i tysk. I konstruktioner, hvor den alene er bærer af en given betydning (irrealis, referat), vil udeladelse af konjunktiv betyde bortfald af den pågældende betydning. 
De to sprogs forskellige strategier i forbindelse med formsammenfald (fransk har intet problem med formsammenfald, mens tysk har en omskrivningsstrategi til at undgå sammenfaldende former og sikre en tydelig konjunktiv), synes logisk i lyset af disse forskellige mønstre.

Modusoppositionen på de to sprog dækker over forskellige betydningsoppositioner. På fransk kan modusoppositionen beskrives som en forskel i assertion og ikke-assertion, mens konjunktiv på tysk har to hovedfunktioner, irrealis og referat. Indikativ på tysk er neutral; den er ikke bærer af irrealis- eller referatbetydning, men kan optræde i konstruktioner, hvor disse betydninger etableres af andre elementer. Den betydningsmæssige forskel kommer tydeligt til udtryk i de konstruktioner, hvor begge modi kan forekomme i de samme syntaktiske omgivelser - i kompletivsætninger for matrixprædikater med to mulige læsninger (38) og (39). Her kan indikativ bruges til at angive kompletivsætningen som præsupponeret, mens det interessant nok er konjunktiv, der på fransk udfylder denne rolle (jf. (27)).

\section{Konklusion}

I det foregående har vi peget på en række forskelle på modusoppositionen i fransk og tysk både hvad angår form og funktion. Tysk er kendetegnet ved relativt mange former, der formelt set kan ses som paralleller til de indikativiske tempusformer, men som funktionelt set i højere grad har modal end temporal betydning. Formerne kan grupperes i to systemer, der fordeler sig over tre funktionsområder. Der kan iagttages en del synkretisme, som dog afhjælpes i kraft af omskrivning. Alt i alt synes det tyske system at betone muligheden for tydelige modusformer, hvilket naturligvis især er relevant, når konjunktiven alene angiver en bestemt funktion.

I modsætning til tysk har fransk et reduceret antal konjunktivformer, idet der ved ganske mange verber er synkretisme mellem indikativ og konjunktiv. Dette forhold kan måske forklare, hvorfor konjunktiv er et ledsætningsfænomen på fransk. Hvis konjunktiv kun i begrænset omfang er semantisk bærende, har man på fransk heller ikke brug for en tydelig konjunktivform, som tilfældet er på tysk.

Dog er den franske konjunktiv i visse tilfælde semantisk bærende, dvs. hvor den ene og alene kan ændre læsningen af matrixprædikatet, hvorved ledsætningsindholdet med indikativ bliver asserteret og med konjunktiv ikke-asserteret.

Sammenligningen illustrerer dels, hvordan en sammenlignelig grammatisk kategori kan udfolde sig forskelligt og finde forskellig anvendelse i to 
forskellige sprog, og dels skærper den synet på, hvordan forminventaret på et givet sprog indretter sig efter de funktioner, den givne form skal varetage.

\section{Om forfatterne}

Alexandra Holsting, ph.d., Institut for Sprog og Kommunikation, Syddansk Universitet.

Jan Lindschouw, ph.d., Institut for Engelsk, Germansk og Romansk, Københavns Universitet.

\section{Litteratur}

Bausch, K.-H. (1979): Modalität und Konjunktivgebrauch in der gesprochenen deutschen Standardsprache. Sprachsystem, Sprachvariation und Sprachwandel im heutigen Deutsch. München: Hueber.

Blumenthal, P. (1987): Sprachvergleich Deutsch - Französisch. Tübingen: Niemeyer.

Boer, G. de (1947): Syntaxe du français moderne. Leiden: Universitaire Pers Leiden.

Bravo, N.F. (1980): Geschichte der indirekten Rede im Deutschen vom siebzehnten Jahrhundert bis zur Gegenwart. Deutsche Sprache 8, 97-132.

Brunot, F. (1922): La Pensée et la langue. Paris: Masson et Cie.

Celle, A. (2006): Temps et modalité. L'anglais, le français et l'allemand en contraste. Bern: Peter Lang.

Eisenberg, P. (2006): Grundriss der deutschen Grammatik (3. udg.). Stuttgart, Weimar: J.B. Metzler.

Fabricius-Hansen, C. (2000): Die Geheimnisse der deutschen würdeKonstruktion. I: Deutsche Grammatik in Theorie und Praxis. Thieroff, R. et al. (red.). Tübingen, Niemeyer, 83-96.

Fabricius-Hansen, C. (2009): Das Verb. I: Duden. Die Grammatik (8. udg.). Mannheim, Wien, Zürich: Dudenverlag, 389-566.

Foulet, L. (1968 [1919]): Petite syntaxe de l'ancien français. Paris: Librairie Honoré Champion.

Glinz, H. (1994): Grammatiken im Vergleich: Deutsch - Französisch - EnglischLatein. Formen - Bedeutungen - Verstehen. Tübingen: Niemeyer.

Harris, M. (1974): The subjunctive mood as a changing category in Romance. I: Historical linguistics II. Anderson, J.M. \& Jones, C. (red.). Amsterdam, Oxford: North-Holland Publishing Company, 169-188. Hooper, J.B. (1975): On assertive predicates. I: Syntax and Semantics 4. 
Kimball, J.P. (red.). New York: Academic Press, 91-124.

Jakobsen, L.F. (2013): Paradigms - a somewhat neglected grammatical concept. Rask 38, 197-218.

Jakobsen, L.F. \& Heltoft, L. (2012): Paradigm formation: Changes of function and structures in German and Danish mood systems. Acta Linguistica Hafniensia 44 (1), 77-107.

Jørgensen, P. (1995): Tysk Grammatik I-III (3. udg.). København: Gads Forlag.

Kaufmann, G. (1976): Die indirekte Rede und mit ihr konkurrierende Formen der Redeerwähnung. München: Hueber.

Korzen, H. (1999): Principper for opstillingen af modus i kompletivsætninger på fransk. I: Ny forskning i grammatik 6. Bache, C., Heltoft, L. \& Herslund, M. (red.). Odense: Odense Universitetsforlag, 181-203.

Kragh, K.J. (2010): Le remplacement de l'imparfait du subjonctif par le présent du subjonctif considéré dans une perspective de grammaticalisation. Copenhagen: Museum Tusculanum Press.

Le Bidois, G. \& Le Bidois, R. (1935): Syntaxe du français moderne I-II. Paris: Editions Picard.

Lindschouw,J. (2011): Etude des modes dans le système concessif en français du 16 e au 20 e siècle et en espagnol moderne. Evolution, assertion et grammaticalisation. København: Museum Tusculanum Press.

Lindschouw, J. (2017): Tense, aspect, and mood. I: Manual of Romance morphosyntax and syntax. Dufter, A. \& Stark, E. (red.): Berlin, Boston: de Gruyter, 397-448.

Martin, R. (1992 [1983]): Pour une logique du sens. Paris: Presses Universitaires de France.

Molen, W. van der (1923): Le subjonctif, sa valeur psychologique et son emploi dans la langue parlée. Amsterdam: Zaltbommel.

Pedersen, J., Spang-Hanssen, E. \& Vikner, C. (1994 [1980]): Fransk grammatik. København: Akademisk Forlag.

Prebensen, H. (2002): Modus, modalitet og modeller. Om den franske konjunktivs betydning. I: Lingvistiske essays til minde om Finn Sørensen. Baron, I., Herslund, M. \& Müller, H.H. (red.). København: Samfundslitteratur, 97-107.

Rothstein, B. \& Thieroff, R. (2010): Mood in the languages of Europe. Amsterdam, Philadelphia: Benjamins.

Thieroff, R. (2010): Moods, moods, moods. I: Mood in the Languages of Europe. Rothstein, B. \& Thieroff, R. (red.). Amsterdam, Philadelphia: Benjamins, 133-154. 
Togeby, K. (1982): Grammaire française. Volume II: Les Formes Personnelles du Verbe. København: Akademisk Forlag.

Touratier, C. (1996): Le système verbal français. Paris: Armand Colin.

Weber, H. (1954): Das Tempussystem des Deutschen und Französischen. Übersetzungs- und Strukturprobleme. Bern: Francke.

Zemb, J.M. (1978): Vergleichende Grammatik Französisch-Deutsch. Teil I. Mannheim: Dudenverlag.

Zifonun, G., Ludger, H. \& Strecker, B. (1997): Grammatik der deutschen Sprache. Berlin, New York: de Gruyter. 